\title{
HYDROPHOBIC AND ANTIBACTERIAL PROPERTIES OF LASER MICROMACHINED STEEL SURFACES
}

\author{
Šimon SYROVÁTKA ${ }^{1}$, Jiř́ MARTAN ${ }^{1,2}$ \\ ${ }^{1}$ Department of Machining Technology, University of West Bohemia, Univerzitni 8, 30100 Pilsen, \\ Czech Republic, EU, simonsyr@students.zcu.cz \\ ${ }^{2}$ New Technologies Research Centre (NTC), University of West Bohemia, Univerzitni 8, 30100 Pilsen, \\ Czech Republic, EU, jmartan@ntc.zcu.cz
}

https://doi.org/10.37904/metal.2020.3554

\begin{abstract}
One of the main benefits of ultrashort laser micromachining is the possibility of preparing various surface structures, including a diversity of shapes and dimensions. The goal of this paper was to fabricate hydrophobic surface structures and to study coherency between the wettability and antibacterial properties of these structures for their further ways of application. The picosecond laser with a galvanometer scanner was used in the experiment for the fabrication of several types of surface structures. The next part of the experiment was testing of fabricated structures. Their wettability and antibacterial properties were tested and analyzed during several months. Tests showed that the fabrication of surface structures changed the wettability of the tested samples (the samples became more hydrophobic) and also showed that these structures affect their bacterial properties.
\end{abstract}

Keywords: Picosecond laser, stainless steel AISI 316L, wettability, hydrophobicity, antibacterial properties

\section{INTRODUCTION}

Nowadays, the laser technologies belong between technologies that are very innovative. By using laser, it is possible to fabricate microscopic entities in a very short time with very high accuracy. Specific changes of surface structure can cause the transition of the physical and chemical properties of the surface. These controlled changes of surface properties could be useful in many industries such as machine, medical, energetic industry, etc.

Wettability represents a property of surface which describes the ability to adhere or repulse liquid to/from the surface. The most used quantity to describe the wettability is the contact angle $(C A)$. It is defined as the size of the angle between surface and tangent to the surface of the liquid droplet. The surfaces can be divided into three main groups according to the size of their $C A$ : hydrophilic surfaces $\left(C A<90^{\circ}\right)$, hydrophobic surfaces $\left(90^{\circ}<C A>150^{\circ}\right)$ and superhydrophobic surfaces $\left(C A>150^{\circ}\right)[1,2]$. Hydrophobic surfaces have a wide range of applications, e.g., anti-icing surfaces of airplane wings, easily washable surfaces, surfaces of medical equipment, etc. [3,4]. In terms of the process of contact angle measuring, there are several different methods (e.g., sliding angle measurement, the $C A$ hysteresis measurement, the static contact angle measurement, Wilhelmy balance method, etc.). One of the most used methods is the static contact angle measurement method [5].

Bacterial adhesion process comprises the initial adhesion and the main adhesion to the surface. Many factors such as properties of the bacteria, conditions of the surrounding environment, properties of the surfaces influence the initial adhesion. The main adhesion can be amplified or inhibited by properties of surfaces, including topography of surface. This main adhesion is divided into two phases. First phase is very quick and it represents only the primary interaction between bacteria and surface. During the second phase, specific and nonspecific interactions occur between proteins on the surface of the bacteria and binding molecules of the 
material. Studies show that some bacteria species are attracted by hydrophilic surfaces (e.g., Staphylococcus aureus, Escherichia coli), while other are attracted by hydrophobic surfaces (e.g., Pseudoxanthomonas taiwanesis, Staphylococcus epidermidis). It was also observed, that superhydrophobic surfaces reduce the bacterial adhesion, probably because of the air bubbles that are created in surface microstructures [6,7].

The hydrophobic surface structures may consist of different types of shapes. Some of them are inspired by nature (e.g., lotus leaf hierarchical structures), however, commonly used geometric entities in the fabrication of hydrophobic structures are grooves, micro holes, papillae, etc. [8-12].

\section{EXPERIMENTAL SECTION}

The experiment consisted of designing and fabricating eleven surface structures (Figure 1) which should change the wettability of testing material. Dimensions of fabricated structures were from $10 \mu \mathrm{m}$ up to $150 \mu \mathrm{m}$. The stainless steel AISI 316L was chosen as the testing material. The chemical composition of test material is shown in Table 1. Designed structures were fabricated by $\mathrm{Nd}$ : YAG picosecond laser with these properties: wavelength $=532 \mathrm{~nm}$, duration of pulses $=13 \mathrm{ps}$, frequency $=200-1000 \mathrm{kHz}$, average laser power $=12 \mathrm{~W}$.
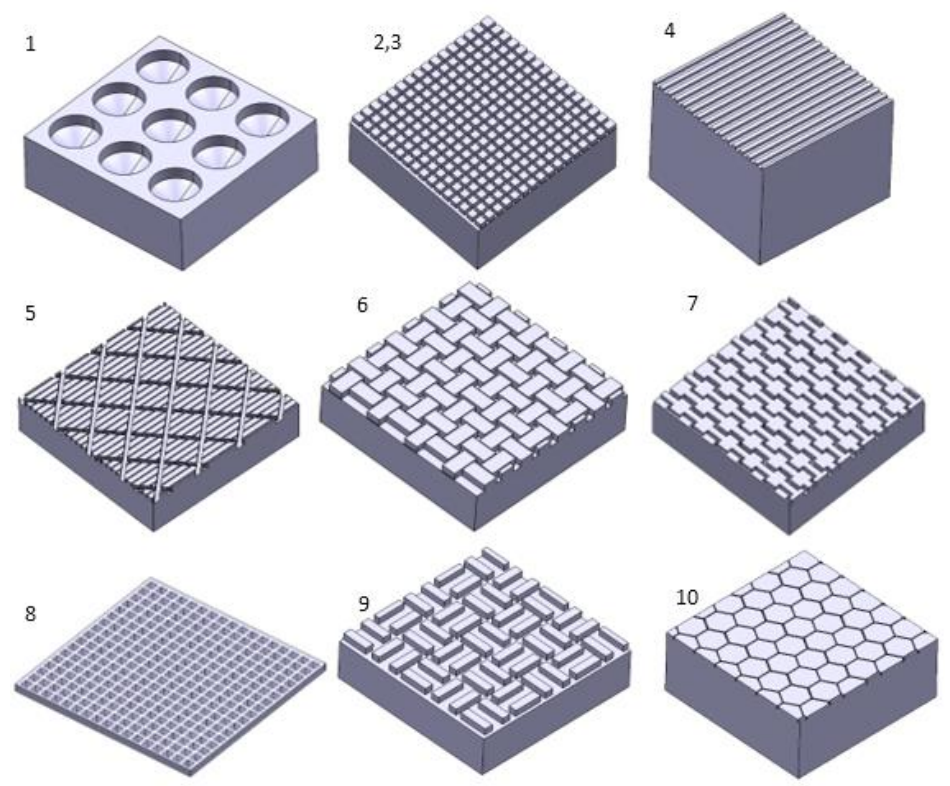

Figure 1 Designed surface structures
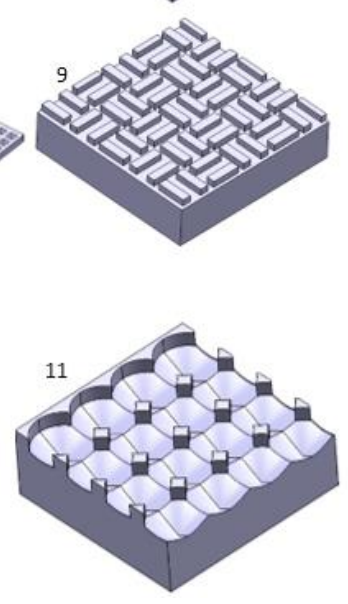

Table 1 The chemical composition of stainless steel AISI 316L (m\%) [13]

\begin{tabular}{|c|c|c|c|c|c|c|c|}
\hline $\mathbf{C}$ & $\mathbf{M n}$ & $\mathbf{S i}$ & $\mathbf{C r}$ & $\mathbf{N i}$ & Mo & $\mathbf{P}$ & $\mathbf{S}$ \\
\hline $\max .0 .03$ & $\max .2 .00$ & $\max .1 .00$ & $16.5-18.5$ & $10-13.0$ & $2-2.5$ & $\max .0 .045$ & $\max .0 .03$ \\
\hline
\end{tabular}

Subsequently, fabricated structures were tested. The wettability of samples was analysed in the first round of testing by using the static contact angle measurement method. Therefore, the device Drop Shape Analyzer DSA30E with distilled water as a testing medium was chosen. The volume of used droplets of distilled water was $1 \mu \mathrm{l}$. Each fabricated structure was tested during two months to observe changes in the CA over time. The time between each measurement was approximately one week. Each sample was tested on five different spots and the average of the measured values was used as a result value.

During second round of testing the antibacterial properties of fabricated structures were tested. Antibacterial properties of 2 out of all 11 structures (the most hydrophobic and less hydrophobic structure) and a reference sample for comparison were analyzed. The dimensions of these chosen surface structures were from $10 \mu \mathrm{m}$ 
up to $23 \mu \mathrm{m}$. The principle of testing was that saline solution that contained bacteria Streptococcus Aureus was deposited on the surface of the tested samples. After that, the samples were left for five hours at room temperature for growing and adhesion of bacteria to the surface. Then the samples were washed to remove non-adherent bacteria of the surface. The process of washing was carried out in two ways. The first way was done by physiological saline solution only. The second way was done by physiological saline solution in ultrasonic purifier (Figure 2). This testing was done for each type of structure five times (always with different samples) for the credibility of the measured data. After that, the samples were examined under the microscope. Then the images that were obtained by the microscope were evaluated by software NIS - Elements BR in order to detect the amount of bacteria that have deposited on the samples.
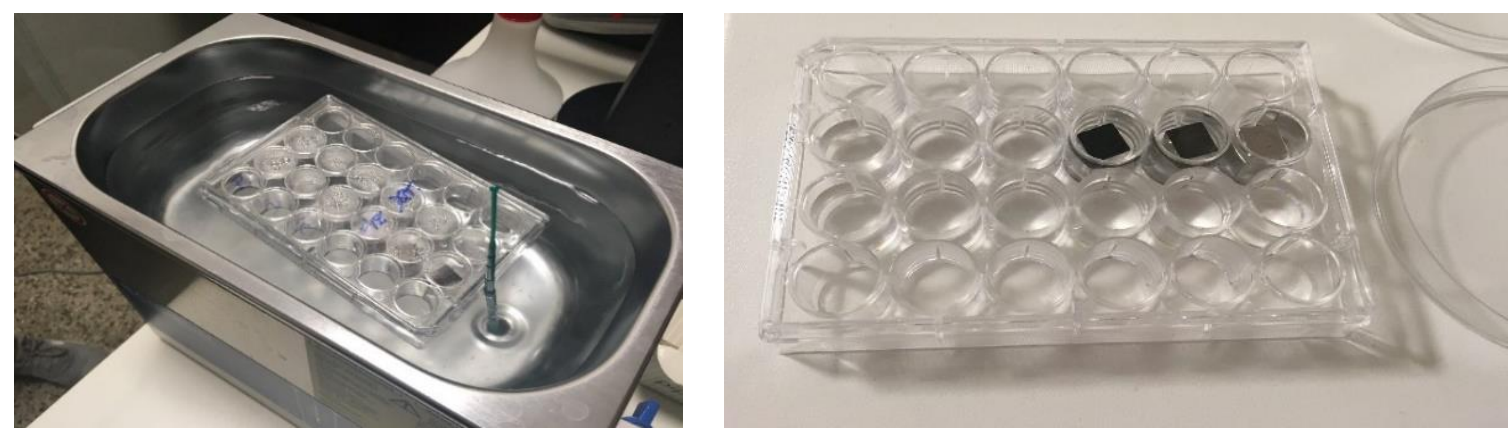

Figure 2 Washing of the samples. Left - washing by physiological saline solution in ultrasonic purifier, right - washing by physiological saline solution only

\section{RESULT AND DISCUSSION}

\subsection{Wettability}

A graph with values from measurement was made for better observation of changing contact angle and for comparison of fabricated structures with original surface (Figure 3).

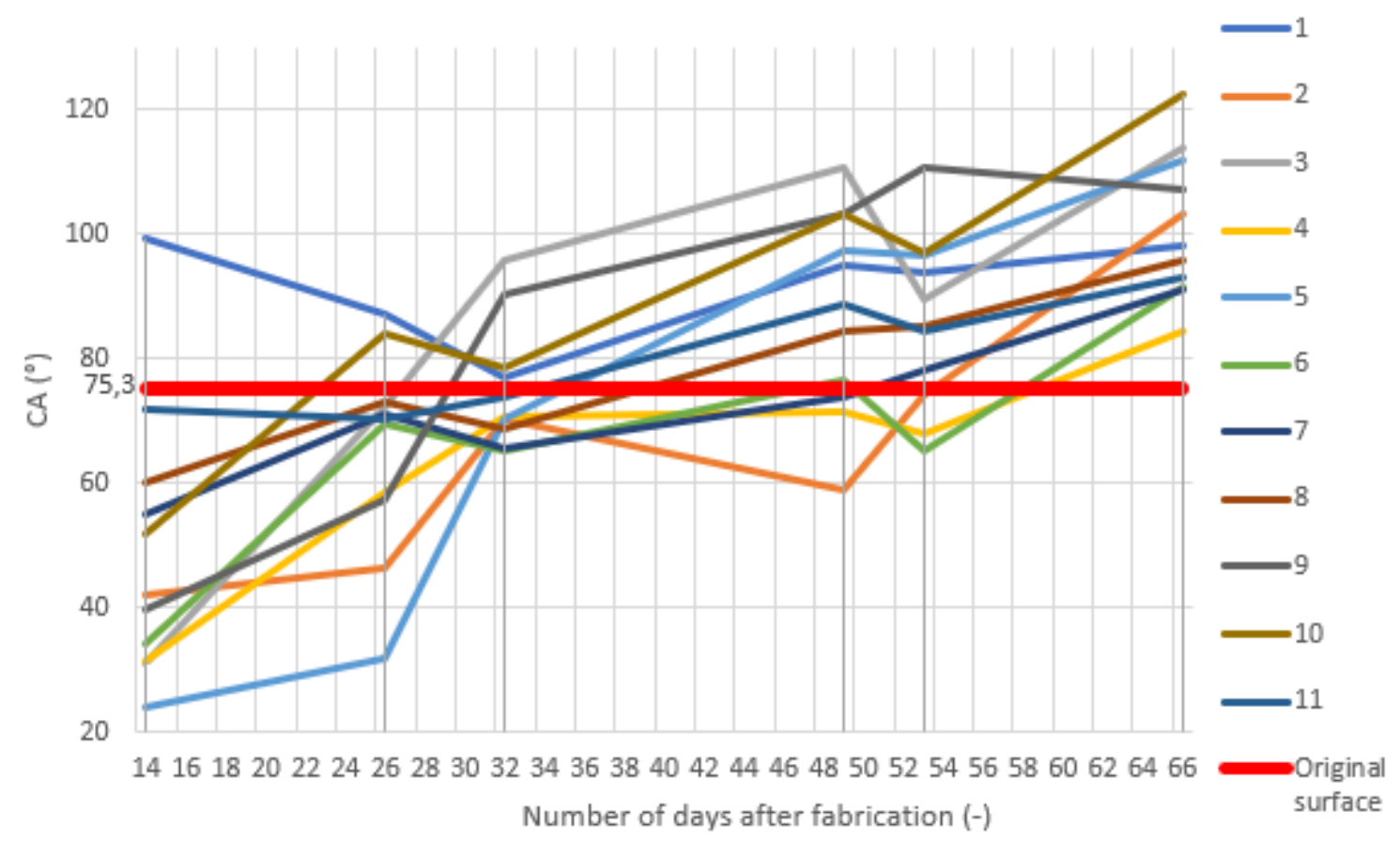

Figure 3 Evolution of $C A$ of surface structures during time 
Based on the wettability testing, it was shown that 10 out of 11 structures became hydrophobic within the 66 days. Also, it is shown that $C A$ of surface structures that were made by the picosecond laser were not constant immediately after the fabrication. The values of $C A$ became stable after some period of time. This problem can be caused by ongoing chemical reactions on the surface which were started after the interaction of the surface with the laser beam. This problem can be solved by the chemical coating of the surface structures immediately after their fabrication [14].

\subsection{Antibacterial properties}

Three samples were chosen for testing of antibacterial properties (sample of the original surface, the sample of structure no. $3\left(C A=113.94^{\circ}\right)$ and the sample of structure no. $\left.4\left(C A=84.43^{\circ}\right)\right)$. Figure 4 shows the number of bacteria (green dots) that were on the samples after the washing processes. Images made by microscope were analysed by the software NIS - Elements BR and the data obtained by this software was graphed (Figure 5).
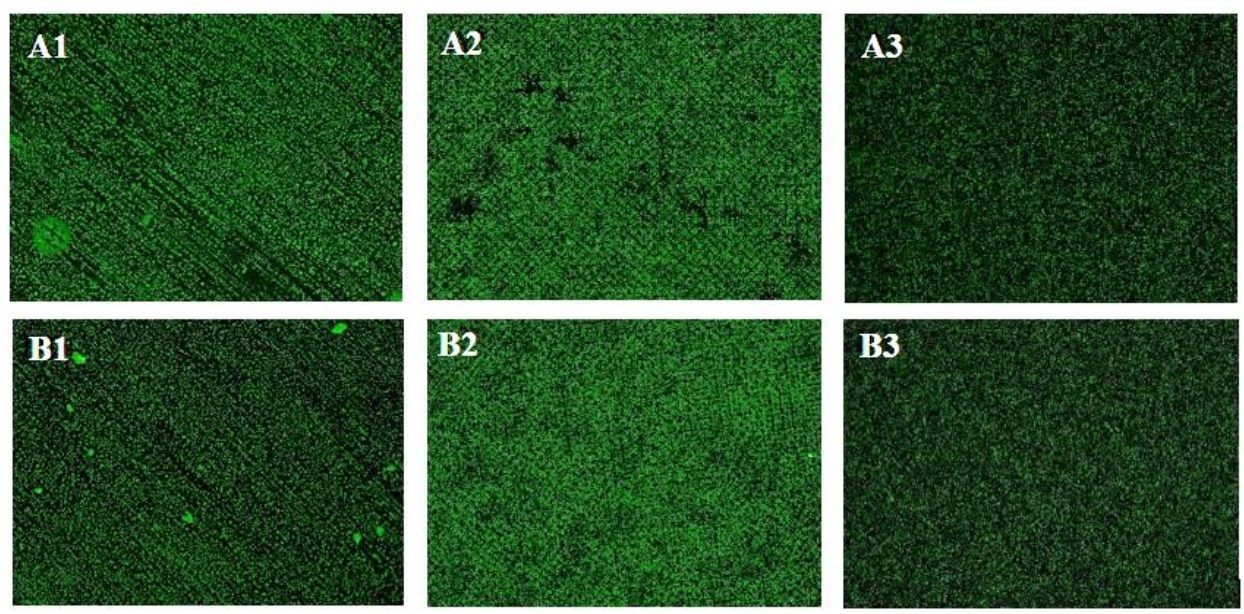

Figure 4 Examples of the images which were analysed by the software NIS - Elements BR. A) Washing by physiological saline solution in ultrasonic purifier, B) Washing by physiological saline solution only.

$1=$ Original surface, $2=$ structure no. $3,3=$ structure no. 4

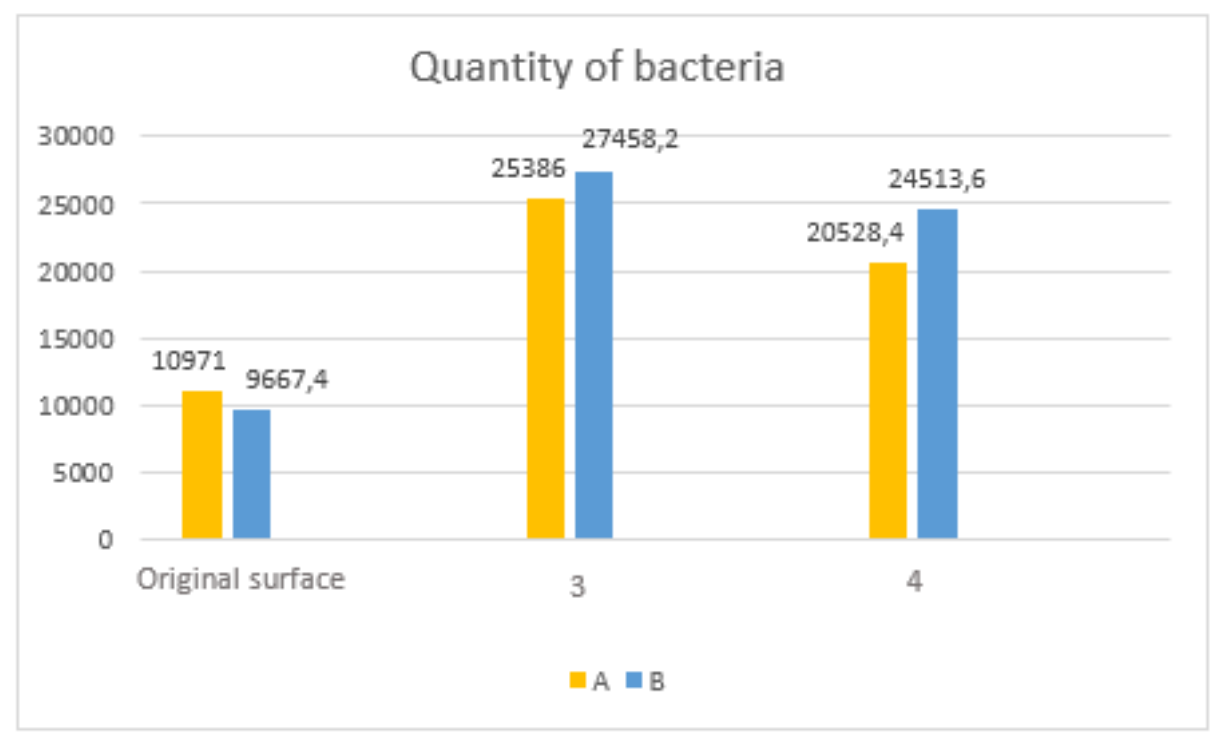

Figure 5 The quantity of bacteria for three samples. A) Washing by physiological saline solution in ultrasonic purifier, B) Washing by physiological saline solution only 
The testing showed that fabrication of surface structures has significant influence on bacterial properties of the surface. The $C A$ of both samples (no. 3, no. 4) was higher than the $C A$ of original surface. It is possible to notice that higher $C A$ of samples correlates with the higher amount of bacteria adhered to the surface. Neither one of the both studied surface modifications did not enhance the antibacterial properties of samples in the case of Streptococcus Aureus. These results indicate that Streptococcus Aureus is possibly the specie of bacteria that is attracted by hydrophobic surfaces. These modified surfaces can be used, for example, in the manufacture of containers which are used for the cultivation of bacteria or in the production of water purifiers where filters with these modified surfaces could capture bacteria and thereby support bioremediation effects. These findings are limited because antibacterial properties of only 2 surface modification were studied and it is possible that antibacterial properties of surface probably could not be connected only to the wettability, but to many other attributes, for example the type of used material, dimensions and shapes of surface structures etc.

\section{CONCLUSION}

Eleven different surface structures were designed and prepared using a picosecond laser. Subsequently, the wettability of all 11 surface structures and antibacterial properties of 2 of them were tested. The wettability of the samples was analysed during the 66-days-long period of time and it was noted that values of $C A$ are not constant immediately after the fabrication. Ten of all structures were found hydrophobic after 66 days. In terms of the antibacterial properties, it was observed that the modified surfaces were more appropriate for the bacterial adhesion of Streptococcus Aureus than the original surface. This finding offers new possibilities for using these surface structures such as water purifiers, containers for bacterial growth, etc.

\section{ACKNOWLEDGEMENTS}

The work has been supported by SGS-2019-008 project. The authors thank HOFMEISTER company for their consultation and possibility of using the picosecond laser system, Department of Physics at the University of West Bohemia for possibility of using the Drop Shape Analyzer and FNUSA for antibacterial properties testing.

\section{REFERENCES}

[1] ZHAO, Tianyi and Lei JIANG. Contact angle measurement of natural materials. Colloids and Surfaces $B$ : Biointerfaces [online]. 2018, 161, 324-330. ISSN 09277765. doi: 10.1016/j.colsurfb.2017.10.056

[2] ÚSTAV PRO HYDRODYNAMIKU AV ČR, v. v. i., 2020. Reologie: Vytvořili jsme nanovlákennou membránu se superhydrofobním povrchem. [online]. [cit. 2020-04-09]. Available from: www.ih.cas.cz/reologie-vytvorili-jsmenanovlakennou-membranu-se-superhydrofobnim-povrchem/

[3] LATTHE, Sanjay S., Rajaram S. SUTAR, Appasaheb K. BHOSALE, Saravanan NAGAPPAN, Chang-Sik HA, Kishor Kumar SADASIVUNI, Shanhu LIU and Ruimin XING. Recent developments in air-trapped superhydrophobic and liquid-infused slippery surfaces for anti-icing application. Progress in Organic Coatings [online]. 2019, 137, 105373. ISSN 03009440. DOI: 10.1016/j.porgcoat.2019.105373

[4] CICEK, S., A. KARACA, I. TORUN, M.S. ONSES and B. UZER. The relationship of surface roughness and wettability of $316 \mathrm{~L}$ stainless steel implants with plastic deformation mechanisms. Materials Today: Proceedings [online]. 2019, 7, 389-393. ISSN 22147853. DOI: 10.1016/j.matpr.2018.11.100

[5] ZHAO, Tianyi and Lei JIANG. Contact angle measurement of natural materials. Colloids and Surfaces B: Biointerfaces [online]. 2018, 161, 324-330. ISSN 09277765. DOI: 10.1016/j.colsurfb.2017.10.056

[6] ZHANG, Xiaoxue, Ling WANG and Erkki LEVÄNEN. Superhydrophobic surfaces for the reduction of bacterial adhesion. RSC Advances [online]. 2013, 3(30), 12003. ISSN 2046-2069. DOI: 10.1039/c3ra40497h 
[7] GITTENS, Rolando A., Lutz SCHEIDELER, Frank RUPP, Sharon L. HYZY, Jürgen GEIS-GERSTORFER, Zvi SCHWARTZ and Barbara D. BOYAN. A review on the wettability of dental implant surfaces II: Biological and clinical aspects. Acta Biomaterialia [online]. 2014, 10(7), 2907-2918. ISSN 17427061. DOI:

10.1016/j.actbio.2014.03.032

[8] LI, Kaikai, Wei YAO, Yingxi XIE, Jie ZHANG, Biaozhang LI, Zhenping WAN, Zhihui ZHANG, Longsheng LU and Yong TANG. A strongly hydrophobic and serum-repelling surface composed of $\mathrm{CrN}$ films deposited on laserpatterned microstructures that was optimized with an orthogonal experiment. Surface and Coatings Technology [online]. 2020, 391, 125708. ISSN 02578972. DOI: 10.1016/j.surfcoat.2020.125708

[9] CAI, Yukui, Wenlong CHANG, Xichun LUO, Ana M.L. SOUSA, King Hang Aaron LAU and Yi QIN. Superhydrophobic structures on 316L stainless steel surfaces machined by nanosecond pulsed laser. Precision Engineering [online]. 2018, 52, 266-275. ISSN 01416359. DOI: 10.1016/j.precisioneng.2018.01.004

[10] MARTÍNEZ-CALDERON, M., RODRÍGUEZ, A., DIAS-PONTE, A., MORANT-MiÑANA, M. C., GÓMEZARANZADI, M., \& OLAIZOLA, S. M. (2016). Femtosecond laser fabrication of highly hydrophobic stainless steel surface with hierarchical structures fabricated by combining ordered microstructures and LIPSS. Applied Surface Science, 374, 81-89. DOI: 10.1016/j.apsusc.2015.09.261

[11] PAKUŁA, Daniel, Marcin STASZUK, Małgorzata DZIEKOŃSKA, Pavel KOŽMíN and Adam ČERMÁK. Laser Micro-Texturing of Sintered Tool Materials Surface. Materials [online]. 2019, 12(19), 3152. ISSN 19961944. DOI:10.3390/ma12193152

[12] STANKEVIČ, Valdemar, Adam ČERMÁK, Saulius MIKALAUSKAS, Pavel KOŽMíN, Simonas INDRIŠIŪNAS a Gediminas RAČIUKAITIS. Processing of ultra-hard materials with picosecond pulses: From research work to industrial applications. Journal of Laser Applications [online]. 2018, 30(3), 032202. ISSN 1042-346X, $1938-1387$. DOI:10.2351/1.5040633

[13] Italinox, 2019. Chemické složení korozivzdorných ocelí [online]. [cit. 2019-11-26]. Available from: https://www.italinox.cz/plechy/prehled-rozmeru-a-povrchu/chemicke-slozeni

[14] RAVI, Kesavan, Wesley Lock SULEN, Chrystelle BERNARD, Yuji ICHIKAWA and Kazuhiro OGAWA. Fabrication of micro-/nano-structured super-hydrophobic fluorinated polymer coatings by cold-spray. Surface and Coatings Technology [online]. 2019, 373, 17-24. ISSN 02578972. DOI: 10.1016/j.surfcoat.2019.05.078 